\title{
A Glial Cell Line-Derived Neurotrophic Factor-Secreting Clone of the Schwann Cell Line SCTM41 Enhances Survival and Fiber Outgrowth from Embryonic Nigral Neurons Grafted to the Striatum and to the Lesioned Substantia Nigra
}

\author{
Martin J. Wilby, ${ }^{1}$ Simon R. Sinclair, ${ }^{1}$ Elizabeth M. Muir, ${ }^{2}$ Rike Zietlow, ${ }^{1,2}$ Kathryn H. Adcock, ${ }^{1,2}$ \\ Philippe Horellou, ${ }^{4}$ John H. Rogers, ${ }^{2}$ Stephen B. Dunnett, ${ }^{1,3}$ and James W. Fawcett ${ }^{1,2}$ \\ ${ }^{1}$ Medical Research Council, Cambridge Centre for Brain Repair, The E. D. Adrian Building, University of Cambridge, \\ Forvie Site, Robinson Way, Hills Road, Cambridge CB2 2PY, United Kingdom, 2Physiological Laboratory, University of \\ Cambridge, Downing Site, Cambridge CB1 3EG, United Kingdom, ${ }^{3}$ Department of Experimental Psychology, University \\ of Cambridge, Downing Site, Cambridge CB2 3EG, United Kingdom, and ${ }^{4} C 9923$ Centre National de la Recherche \\ Scientifique, Laboratoire de Genetique Moleculaire de la Neurotransmission et des Processus Degeneratifs, Hopital de la \\ Pitie Salpetriere, Batiment CERVI, 75013 Paris, France.
}

We have developed a novel Schwann cell line, SCTM41, derived from postnatal sciatic nerve cultures and have stably transfected a clone with a rat glial cell line-derived neurotrophic factor (GDNF) construct. Coculture with this GDNF-secreting clone enhances in vitro survival and fiber growth of embryonic dopaminergic neurons. In the rat unilateral 6-OHDA lesion model of Parkinson's disease, we have therefore made cografts of these cells with embryonic day 14 ventral mesencephalic grafts and assayed for effects on dopaminergic cell survival and process outgrowth. We show that cografts of GDNF-secreting Schwann cell lines improve the survival of intrastriatal embryonic dopaminergic neuronal grafts and improve neurite out- growth into the host neuropil but have no additional effect on amphetamine-induced rotation. We next looked to see whether bridge grafts of GDNF-secreting SCTM41 cells would promote the growth of axons to their striatal targets from dopaminergic neurons implanted orthotopically into the 6-OHDA-lesioned substantia nigra. We show that such bridge grafts increase the survival of implanted embryonic dopaminergic neurons and promote the growth of axons through the grafts to the striatum.

Key words: bridge graft; GDNF; Parkinson's disease; 6-OHDA; Schwann cells; SCTM41; substantia nigra; neuronal graft
The anatomical and behavioral repair mediated by intrastriatal embryonic nigral grafts in animal models of Parkinson's disease (Björklund and Stenevi 1979; Perlow et al., 1979; Dunnett, 1991; Freed et al., 1991; Annett et al., 1994), particularly the 6-hydroxydopamine (6-OHDA) model (Ungerstedt, 1968), has paved the way for human grafting trials. Although clinical benefits have been shown with nigral grafts implanted ectopically within the parkinsonian striatum (Lindvall et al., 1990; Kordower et al., 1995; Leroy et al., 1996; Olanow et al., 1996, Wenning et al., 1997), they do not provide a complete cure (Lindvall, 1997). There are at present two main limitations to striatally placed grafts. Survival of dopaminergic neurons after standard implantation procedures is only between 5 and 10\% (Björklund, 1991), and only some of the symptoms of parkinsonism are alleviated, probably because with ectopic placement of dopaminergic tissue, the whole nigrostriatal circuitry cannot be restored (Dunnett et al., 1987).

Homotopic placement of grafted nigral tissue should, in principle, be much more effective, but only if connections between a graft in the ventral mesencephalon (VM) and distant striatal

\footnotetext{
Received Aug. 26, 1998; revised Dec. 28, 1998; accepted Jan. 4, 1999.

This work was supported by the Wellcome Trust, the Medical Research Council, Action Research, and the International Spinal Research Trust. We thank Eduardo Torres, Dorothy Gibson, Claire Ellis, and Trevor Humby for their assistance.

Correspondence should be addressed to J. Fawcett, Department of Physiology, Downing Street, Cambridge CB2 3EG, United Kingdom.

Copyright (C) 1999 Society for Neuroscience $\quad 0270-6474 / 99 / 192301-12 \$ 05.00 / 0$
}

targets can be established. Homotopically placed nigral grafts do not grow their axons to the striatum through the inhibitory milieu of the adult brain (Björklund et al., 1983) but nevertheless have some restoratory effect because of connections made within the substantia nigra (Nikkhah et al., 1995). However, if provided with permissive substrates connecting them with their striatal target, nigral grafts can also make connections to the striatum. Such "bridges" have included peripheral nerve (Aguayo et al., 1984), embryonic striatal tissue (Dunnett et al., 1989), a Schwann cell line (Brecknell et al., 1996a,b), excitotoxic lesions within the neuropil (Zhou et al., 1996), and glial cell line-derived neurotrophic factor (GDNF) (Wang et al., 1996). The fiber growth achieved by these strategies is sparse, and intracerebral bridge grafts have only achieved a maximum of a few hundred ingrowing fibers. Even this small number of axons has achieved partial restoration of function (Dunnett et al., 1989; Brecknell et al., 1996a,b). The search for an optimal bridge tissue therefore continues.

An ideal bridge graft material should be able to improve the survival of grafted dopaminergic neurons, as well as promote growth of their axons. The most potent survival factors are members of the transforming growth factor- $\beta$ family of molecules, particularly GDNF and neurturin. They have been shown to support the survival of embryonic nigral neurons in vitro (Lin et al., 1993), in oculo (Johansson et al., 1995), and intrastriatally (Rosenblad et al., 1996; Sinclair et al., 1996), and also to promote 
axon growth from dopaminergic neurons (Rosenblad et al., 1996; Sinclair et al., 1996; Wang et al., 1996). Physiologically, GDNF is expressed by the basal ganglia during development (Nosrat et al., 1996), whereas developing dopaminergic neurons express the GDNF receptor (GDNFRa-1) and the necessary coreceptor Ret (Nosrat et al., 1997).

Schwann cells provide the substrate for peripheral nerve regeneration and can also mediate regeneration of CNS axons, including those of the nigrostriatal tract (David and Aguayo, 1981; Gage et al., 1985; Kromer and Cornbrooks, 1985; Xu et al., 1995). This can be attributed to their expression of axonotrophic molecules within their membranes (Ard et al., 1987; Bixby et al., 1988), extracellular matrix (Ide et al., 1983; Bunge et al., 1989; Martini, 1994), and their production of diffusible tropic factors (Politis et al., 1982). Moreover, a variety of trophic molecules are known to be produced by Schwann cells, including in some circumstances GDNF (Lindholm et al., 1987; Meyer et al., 1992; Rufer et al., 1994; Lee et al., 1995; Hammarberg et al., 1996). In this study, we have combined the neurotrophic and neurotropic effects of GDNF and Schwann cells to produce bridge grafts and cografts that increase the survival of dopaminergic grafts and promote nigrostriatal connectivity.

\section{MATERIALS AND METHODS}

\section{Generation of Schwann cell lines}

The cell line SCTM41 was derived from neonatal rat sciatic nerve cultures purified from Schwann cells. All cells were cultured in DMEM (Life Technologies, Paisley, Scotland) supplemented with penicillinstreptomycin (100 U/ml; Life Technologies) and $10 \%$ fetal calf serum (FCS). Nerves were obtained from postnatal day 2 (P2) sciatic nerve from CD rats (Charles River Laboratories, Margate, UK), placed in L-15 medium, and cleared of blood vessels, musculature, and their epineurial sheaths. Thereafter, they were placed into a $35-\mathrm{mm}$-diameter plastic dish containing trypsin (0.1\%; Sigma, St. Louis, MO) and collagenase $(0.03 \%$; Sigma $)$, cut very finely using dissection scissors, and placed in an incubator at $37^{\circ} \mathrm{C}$ and $10 \% \mathrm{CO}_{2}$ for $30 \mathrm{~min}$. After this incubation, an equal volume of triturating solution [ $300 \mathrm{mg}$ of BSA, $1 \mathrm{mg}$ of DNase, 50 $\mathrm{mg}$ of trypsin inhibitor, and $100 \mathrm{ml}$ of HBSS (all per ml of HBSS) (all from Sigma)] was added, and the whole mixture was gently triturated using a flame-polished glass Pasteur pipette. Having spun down the cells into a pellet by centrifugation at $1000 \mathrm{rpm}$ for 3-5 min, the cells were then resuspended in DMEM with $10 \%$ FCS and plated on poly-L-lysine $\left(0.01 \%\right.$; Sigma) at a density of 5000 cells $/ \mathrm{mm}^{2}$. On the following day, cells were treated with cytosine arabinoside (Ara-C) $\left(1 \times 10^{-5} \mathrm{M}\right.$; Sigma) for $3 \mathrm{~d}$. After $2 \mathrm{~d}$ in normal untreated FCS-containing medium, the Ara-C was again applied for an additional $3 \mathrm{~d}$. The few remaining fibroblast contaminants were then killed via complement-mediated lysis using rabbit serum (a gift from R. Oldroyd, Cambridge University, Cambridge, UK) and the IgM class anti-Thy1.1 (1:1000; Serotec, Oxford, UK). Subsequently, the Schwann cells (>98\% pure) were maintained in FCS supplemented with bovine pituitary extract $(10 \mathrm{mg} / \mathrm{ml}$; Sigma $)$ and forskolin ( $2 \mathrm{mM}$; Sigma).

The SCTM41 cell line is based on the constitutive expression of a synthetic ligand-gated proto-oncogene, in this instance, tamoxifenregulated human c-Myc. The retrovirus pBpuro MycMERG525R, which carries both a puromycin-resistance gene and the DNA encoding the c-myc/G525R (a mutant murine oestrogen receptor) (Danielian et al., 1993) fusion protein (Littlewood et al., 1995), was used for the transformation process. Supernatant from producer cell lines (a generous gift from Trevor Littlewood, Imperial Cancer Research Fund Laboratories, London, UK) was collected every $2 \mathrm{~d}$, passed through a $0.45 \mathrm{~mm}$ Millipore (Bedford, MA) filter, and used as the source of retrovirus.

Confluent cultures of purified Schwann cells (see above) were incubated with retrovirus-containing supernatant in the presence of $8 \mu \mathrm{g} / \mathrm{ml}$ Polybrene. After $4 \mathrm{hr}$, the supernatant was removed and replaced with DMEM and $10 \%$ FCS and maintained at $37^{\circ} \mathrm{C}$. After $3 \mathrm{~d}, 5 \mathrm{mg} / \mathrm{ml}$ puromycin and $100 \mathrm{~nm}$ 4-hydroxytamoxifen (Semat) was included in the culture medium (CM) to select for virus-infected cells. After an additional $10 \mathrm{~d}$, puromycin-resistant cells were replated in a 96-well plate at a density of 0.5 cells per well $(50 \mathrm{ml}$ volume) and maintained in the tamoxifen-containing medium. Ten days later, colonies were observed in a proportion of the wells. One of these, SCTM41, was selected on the basis of morphology, expression of Schwann cell markers, and promotion of axon growth (see below).

\section{Transfection with the rat GDNF construct}

The relevant portion of GDNF cDNA, including the signal sequence, was cut out of Bluescript vector (Stratagene, La Jolla, CA) with the restriction enzymes $X b a \mathrm{I}$ and $K p n \mathrm{I}$ and inserted into the equivalent site of the polylinker in the mammalian expression vector pcDNA 3.1 (Invitrogen, San Diego, CA). In this vector, transcription of the inserted gene is under the control of the cytomegalovirus promoter, which has been shown to drive high levels of gene expression in a wide variety of cell types (Pasleau et al., 1985).

The transfection procedure was as follows. One $75 \mathrm{ml}$ flask containing SCTM 41 cells at $\sim 50 \%$ confluence was incubated with $15 \mu \mathrm{g}$ of plasmid mixed with lipofectamine in $5 \mathrm{ml}$ of Optimem, a serum-free CM (Life Technologies). After $5 \mathrm{hr}$, incubation of an equal volume of medium containing $20 \%$ FCS was added, and the cells were incubated overnight. The following day, the medium was removed and replaced with "normal" SCTM41 medium (DMEM with 10\% FCS, $100 \mathrm{~nm}$ tamoxifen, and $0.4 \%$ penicillin-streptomycin). After an additional $72 \mathrm{hr}$, the cells were selected with G418 at a concentration of $800 \mu \mathrm{g} / \mathrm{ml}$.

After two weeks of selection, the G418 was removed. Clones were then generated by plating cells into 96-well plates at densities of one, two, or four cells per well. Individual clones were then expanded and analyzed for GDNF secretion using an ELISA assay. The analysis was conducted by collecting medium from $25 \mathrm{ml}$ flasks while the cells were dividing unhindered by confluence.

\section{Schwann cell-specific marker expression by SCTM41}

The novel SCTM41 cell line was screened for the Schwann cell markers low-affinity nerve growth factor receptor p75 (LNGFR), the calcium binding protein S100, laminin, and growth associated protein 43 (GAP43). The nonSchwann cell-specific marker Thy1.1 (a characteristic surface protein of fibroblasts) was also tested. Protein expression was assessed using indirect immunofluorescent labeling. SCTM41 cells were plated onto poly-L-lysine-coated sterile $13 \mathrm{~mm}$ coverslips at a density of $10^{5}$ cells per coverslip. The antibodies to S100 (Dako, Glostrup, Denmark), LNGFR (Boehringer Mannheim, Mannheim, Germany), and GAP-43 (a generous gift from G. Wilkin, Department of Biochemistry, Imperial College, London, UK) were all used at a dilution of 1:2000, whereas the anti-mouse Thy1.1 was used at 1:1000. The tissue was fixed in $4 \%$ paraformaldehyde for $30 \mathrm{~min}$, blocked with either PBS-Triton X-100 $(0.2 \%)$ and 5\% NGS (in the case of GAP-43 and S100) or the same solution lacking Triton X-100 (LNGFR and Thy1.1), and then incubated for $45 \mathrm{~min}$ (at room temperature) with the primary antibody (in a $1 \%$ NGS solution). Secondary antibodies were either anti-mouse or antirabbit biotinylated conjugates (1:200 in 1\% NGS; Boehringer Mannheim). Streptavidin conjugated rhodamine tertiaries allowed visualization (1:200 in 1\% NGS; Boehringer Mannheim).

\section{Preparation of embryonic ventral mesencephalic cultures}

Ten to fourteen embryos of a single litter [embryonic day 14 (E14); crown-rump length, $11 \mathrm{~mm}$ ) were removed by hysterotomy and kept in HBSS (Life Technologies) while the VM was dissected free. After removal of the mesencephalic flexure, tissue pieces were incubated for 10 min in $0.01 \%$ trypsin (Worthington, Freehold, NJ), followed by trituration in triturating solution [(in $\mathrm{mg} / \mathrm{ml} \mathrm{HBSS}$ ): 10 bovine serum albumen, 0.5 trypsin inhibitor, and 0.01 DNase (all from Sigma)] and finally in CM [10\% FCS (Sera-Lab, Sussex, UK), 1\% penicillin, streptomycin, and fungizone in DMEM (all from Life Technologies)]. Tissue was then triturated with $\sim 12$ strokes of a flame-polished Pasteur pipette in $1 \mathrm{ml}$ of fresh CM.

\section{Cocultures of GDNF-secreting Schwann cells with embryonic VM}

SCTM41 or SCTM41 GDNF cells were plated onto poly-L-lysine-coated sterile $13 \mathrm{~mm}$ coverslips at a density of $10^{5}$ cells per coverslip and were allowed to grow to confluence in normal tamoxifen-containing medium (see above). Embryonic VM was plated out at a density of $10^{5}$ cells per coverslip on either monolayers of SCTM41 $(n=11)$ or SCTM41 GDNF $(n=11)$. Poly-L-lysine-coated coverslips $(n=12)$ served as control. From the moment of plating VM onto the substrates, tamoxifen-free CM was 


\section{A. Co-graft experiment}

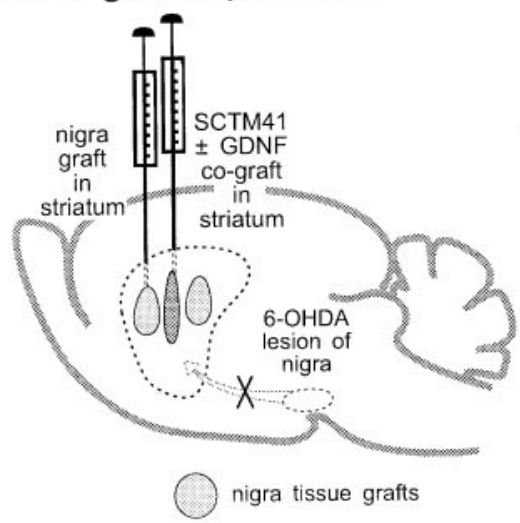

\section{B. Bridge graft experiment}

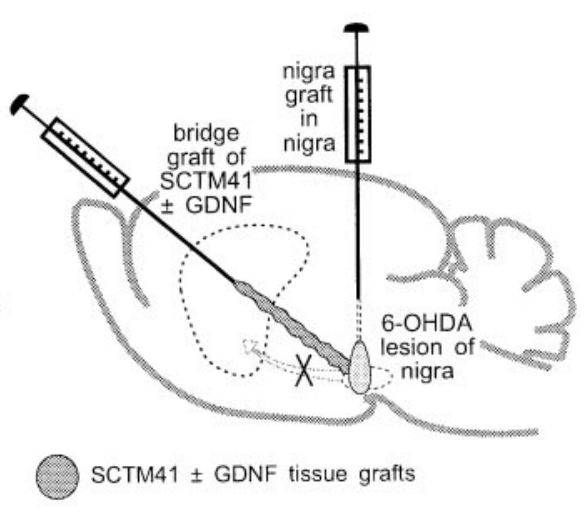

Figure 1. The types of transplant performed in these experiments. $A$, In the cograft experiment, the nigrostriatal pathway was lesioned with 6-OHDA, and then after checking for the completeness of the lesions using amphetamine-induced rotation, grafts of SCTM cells and dissociated nigra were made to the striatum. $B$, In the bridge graft experiment, the nigra was lesioned with 6-OHDA, the animals were rotated, a bridge graft of SCTM cells was inserted between nigra and striatum, and then $2 \mathrm{~d}$ later a nigral graft was placed in the nigra. used. After $24 \mathrm{hr}$, coverslips were fixed in $4 \%$ paraformaldehyde and assessed for tyrosine hydroxylase (TH) expression. Nonspecific staining was blocked with 5\% NGS, and then the cells were labeled with primary antibodies to TH (1:400; Boehringer Mannheim) overnight, followed by biotinylated goat anti-mouse Ig (1:200; Boehringer Mannheim) for $1 \mathrm{hr}$ and sulforhodamine 101-labeled streptavidin (1:200; Boehringer Mannheim) for $1 \mathrm{hr}$ (all antibodies in PBS, pH 7.4, 1\% NGS, and $0.2 \%$ Triton $\mathrm{X}-100$, followed by three washes in PBS). Stained coverslips were mounted onto glass slides with glycerol/PBS (1:1).

The number of TH-positive cells was determined under a fluorescent microscope by counting the number of immunoreactive cells in two orthogonal 0.5 -mm-wide strips across the coverslip. The maximum fiber lengths (distance from the cell body to tip of its longest process) of $\sim 50$ TH-positive neurons per substrate were measured using a calibrated graticule.

\section{Cografts of embryonic nigra with a GDNF-secreting Schwann cell line within the dopamine-depleted striatum}

Animals. Thirty six young adult female rats of the CD strain (Charles River Laboratories) were housed in groups of six under a natural light/dark cycle, with food and water available ad libitum. Graft tissues were obtained from embryos of the same outbred strain.

6-OHDA lesion surgery. All rats received unilateral nigrostriatal lesions with 6-OHDA under halothane-nitrous oxide anesthesia. A $5 \mathrm{mg} / \mathrm{ml}$ solution of 6-OHDA $\mathrm{HBr}$ (free base $3.3 \mathrm{mg} / \mathrm{ml}$ in $0.02 \%$ ascorbate saline) was infused at a rate of $1 \mathrm{ml} / \mathrm{min}$ over $4 \mathrm{~min}$ via a stereotaxically positioned 30 gauge stainless steel cannula at the following coordinates: anterior (A) from bregma, $-4.4 \mathrm{~mm}$; lateral (L) to the midline, $1.0 \mathrm{~mm}$; and vertical $(\mathrm{V})$ below dura, $7.7 \mathrm{~mm}$; with the nosebar set $2.3 \mathrm{~mm}$ below the interaural line. The cannula was left in situ for diffusion for $1 \mathrm{~min}$ before withdrawal.

Rotation. The rats were assessed for amphetamine-induced rotation in a bank of automated rotometer bowls. Rats were given five 90 min tests, each after intraperitoneal injection of $5 \mathrm{mg} / \mathrm{kg}$ D-amphetamine sulfate, conducted 1 and 2 weeks after initial lesion surgery and at 2, 4, and 6 weeks after grafting. All rats included in the experiments achieved an initial screening criterion of more than seven turns per minute on at least one of the first two tests after the nigrostriatal lesion.

Grafting. The 36 animals with nigrostriatal lesions were divided into three groups matched on the basis of rotation scores on the first two tests. One group received intrastriatal grafts of SCTM41 cells (GDNFtransfected), one received nontransfected SCTM41 cells, and one received sham surgery and injection of vehicle. Each of these groups was further subdivided into two, such that of each set of 12, six also received nigral grafts; the others received sham surgery and the injection of vehicle only. There was one SCTM graft in each animal and two nigral grafts placed nearby (Fig. 1). Table 1 displays this design.

Schwann cell line graft surgery. Three weeks after the 6-OHDA lesion surgery, cell suspensions were made from cultures of both GDNFsecreting and -nonsecreting SCTM41 cells. The procedure was as follows. Culture flasks were washed in PBS containing $0.02 \%$ EDTA. Excess saline was removed, and PBS containing 0.1\% trypsin (Sigma) was added. After $5 \mathrm{~min}$ incubation at $37^{\circ} \mathrm{C}$, triturating solution [(in $\mathrm{mg} / \mathrm{ml} \mathrm{HBSS}$ ): $300 \mathrm{BSA}, 1 \mathrm{DNase}$, and 50 trypsin inhibitor (all from Sigma)] was added, and the whole mixture was gently triturated using a

\begin{tabular}{lll}
\hline $\begin{array}{l}\text { Table 1. Experimental design for nigral-Schwann cell cograft } \\
\text { experiment }\end{array}$ \\
Group & Schwann cell graft & Nigral graft \\
\hline 1 & SCTM41 GDNF & Yes \\
2 & SCTM41 GDNF & Sham \\
3 & SCTM41 & Yes \\
4 & SCTM41 & Sham \\
5 & Sham & Yes \\
6 & Sham & Sham \\
\hline
\end{tabular}

flame-polished glass Pasteur pipette. The cells were spun on a centrif uge and resuspended in grafting medium $(0.002 \%$ DNase in L-15 medium; Life Technologies) at a final density of $\sim 7.0 \times 10^{5} / \mu 1$, with a viability of $>90 \%$.

Experimental animals were reanesthetized with halothane and nitrous oxide and placed in a stereotactic apparatus. An incision was made in the scalp, and a burr hole was made in the skull to expose dura mater. A small volume of either one of the cell suspensions or the buffer vehicle was drawn up into a $10 \mu \mathrm{l}$ grafting syringe (Scientific Glass Engineering), and $2.5 \mu \mathrm{l}$ of this was deposited via its 23 gauge needle over $2.5 \mathrm{~min}$ at stereotactic coordinates from bregma-dura: A, $0.9 \mathrm{~mm}$;, $2.9 \mathrm{~mm}$; V, 4.5 $\mathrm{mm}$. The needle was left in place for $2 \mathrm{~min}$ after the implantation, before removal and closure of the wound. Rats from the three groups underwent surgery in counter-balanced order. Animals were immunosuppressed from this point on with daily intraperitoneal injections of $2 \mathrm{mg}$ of cyclosporin A (Sandoz, Basel, Switzerland) in $0.2 \mathrm{ml}$ of normal saline solution to prevent graft rejection.

Nigral graft surgery. The following day, nigral cell suspensions were prepared according to the same procedure as described for tissue culture, with one VM being suspended in $5 \mu \mathrm{l}$. Cell viability and density counts of aliquots of the suspension in a cytometer, using the trypan blue dye exclusion method, indicated a cell density of $\sim 6.8 \times 10^{5}$ cells $/ \mu 1$ and a viability $>95 \%$.

Half of the rats (the "nigral graft" group; $n=18$ ) received two $2.5 \mu 1$ intrastriatal deposits of graft suspension by direct injection via the 23 gauge needle of the same $10 \mu \mathrm{l}$ glass syringe (Scientific Glass Engineering) positioned at the following stereotaxic coordinates: A, $1.6 \mathrm{~mm}$; $2.4 \mathrm{~mm}$; V, $4.5 \mathrm{~mm}$; and A, $0.2 \mathrm{~mm}$; L, $3.4 \mathrm{~mm}$; V, $4.5 \mathrm{~mm}$. Each graft deposit was infused over $2.5 \mathrm{~min}$, with an additional 2 min allowed for diffusion before retraction of the needle. The remaining rats (the "sham graft" group; $n=18$ ) received identical injections of buffered glucose saline alone. All rats received three additional rotation tests 2,4 , and 6 weeks after graft surgery.

TH immunohistochemistry. After the last rotation test, all animals were perfused with $150 \mathrm{ml}$ of PBS, followed by $250 \mathrm{ml}$ of $10 \%$ formalin in PBS under terminal sodium pentobarbitone anesthesia (Euthatal; May and Baker). The brains were removed, fixed overnight in $10 \%$ formalin, and then transferred to $30 \%$ sucrose for cryoprotection. Coronal sections $(50$ $\mathrm{mm}$ ) were cut from the anterior margin of the corpus callosum to the pons on a freezing sledge microtome, and free-floating sections were 
collected in $0.1 \mathrm{M}$ TRIS-buffered saline, $\mathrm{pH}$ 7.4. Every sixth section was stained immunohistochemically as described by Torres et al. (1993), using a primary antibody against TH (1:10,000; Institut Jacques Boy), followed by a streptavidin-biotin complex kit (Dako). Specific antibody binding was revealed by horseradish peroxidase acting on diaminobenzidine.

Cell counts and analysis of fiber outgrowth from the grafts. Dopamine neuronal survival in the grafts was analyzed by counting all TH-positive neurons in the one-in-six series through the grafts, corrected as described by Abercrombie (1946). Counts were the aggregate of both deposits. The extent of dopaminergic fiber outgrowth was estimated as follows. For each of the two grafts in each brain, the section nearest the midpoint of each graft was taken, and the footprint of the graft was divided vertically into four quartiles. With the assistance of a computer-driven imageanalysis system (Cast-Grid; Olympus, Albertslund, Denmark), three "ladders" (width of $55 \mu \mathrm{m}$, rungs at $80 \mu \mathrm{m}$ intervals) were aligned perpendicularly to the edge of the graft at the three interquartile points, and the numbers of fibers crossing each rung were counted. Values for the three ladders on each side of each graft were pooled. In this way, values of fiber density versus distance from the graft, proximal and distal to the GDNF infusion cannula, were obtained.

To obtain estimates of the volumes of TH-immunoreactive cell bodies in the grafts, the stereological "nucleator" technique was used (Gundersen and Jensen, 1987). Twenty cells in which the nucleus was visible, indicating that the plane of section ran through the middle of the cell, were randomly selected from each medial and lateral graft deposit in each animal and measured, and their volume was calculated. The results were pooled to give a mean cell volume for each animal.

\section{Bridge grafts of GDNF-secreting Schwann cells combined with homotopic nigral graft placement}

A second batch of 36 animals all found to satisfy the post-6-OHDA lesion criterion of more than seven turns per minute ipsilaterally after an amphetamine challenge (as above) were used as subjects for the bridge graft experiment. Animals were divided into three groups of 12 animals. Three different bridge graft substrates were tested: the parent Schwann cell line (SCTM41), the GDNF-secreting variant of this line (SCTM41 GDNF), and a control bridge (grafting medium; vehicle).

Bridge graft surgery. All 36 animals received bridge grafts of one of the three above cell types using a technique modified from that of Dunnett et al. (1989) (Fig. 1). Rats were mounted in a stereotaxic apparatus (Kopf), with the incisor bar set at $10.0 \mathrm{~mm}$ above the level of the ear bars. A burr hole was drilled through the frontal bone ipsilateral to the previous 6-OHDA lesion, and subsequently through the pterygoid bone, to allow free access of a blunt-ended 23 gauge grafting needle to the nigrostriatal pathway. This needle, attached to a $10 \mathrm{ml}$ glass syringe (Scientific Glass Engineering), was mounted at an angle of $44^{\circ}$ to the vertical and lowered to the following coordinates (relative to the midaural point): A, $-0.5 \mathrm{~mm}$; $\mathrm{L}, 2.4 \mathrm{~mm} ; \mathrm{V}, 4.8 \mathrm{~mm}$. A total of $8 \mathrm{ml}$ of graft suspension (containing either SCTM41 cells or SCTM41 GDNF cells at a density of $5 \times 10^{5}$ cells/ $\mu$ l in grafting medium; $0.002 \%$ DNase in L-15) or vehicle (grafting medium alone) was injected in deposits of $0.5 \mu 1$ spaced at $0.5 \mathrm{~mm}$ intervals along the needle track. At each of the 16 locations, the deposit was gently extruded, and the needle was left in place for $30 \mathrm{sec}$ before withdrawing it by $0.5 \mathrm{~mm}$. Animals were immunosuppressed from this point on with daily intraperitoneal injections of $2 \mathrm{mg}$ of cyclosporin A (Sandoz) in $0.2 \mathrm{ml}$ of normal saline solution to prevent graft rejection.

Homotopic nigral graft surgery. Two days after bridge grafting, all animals received two grafts of dissociated embryonic ventral mesencephalic tissue (see above preparation techniques) (Fig. 1). One ventral mesencephalic fragment was suspended in $5 \mu$ l. Cell viability and density counts of aliquots of the suspension in a cytometer, using the trypan blue dye exclusion method, indicated a cell density of $\sim 6.9 \times 10^{5}$ cells $/ \mu \mathrm{l}$ and a viability of $>92 \%$. All rats were reanesthetized and placed in a stereotaxic apparatus, with the incisor bar set $2.3 \mathrm{~mm}$ inferior to the interaural line. They received two $2.5 \mu \mathrm{l}$ of intrastriatal deposits of graft suspension by direct injection via the 23 gauge needle of the same $10 \mu \mathrm{l}$ glass syringe (Scientific Glass Engineering) positioned at stereotaxic coordinates within substantia nigra: A, $-5.0 \mathrm{~mm}$ from bregma; L, -2.9 and $-1.9 \mathrm{~mm}$ from bregma; V, 7.2 and $7.8 \mathrm{~mm}$ from dura mater. Each graft deposit was infused over $2.5 \mathrm{~min}$, with an additional 2 min allowed for diff usion before retraction of the needle.

Fluorogold injections. All animals received tracer injections of fluorogold into their striata. Two days before each animal was to be killed, it was reanesthetized and placed once again into a stereotaxic frame, with
Table 2. Experimental design for the bridge graft experiment

\begin{tabular}{llll} 
Time-bridge material & Vehicle & SCTM41 & SCTM41 GDNF \\
\hline $\begin{array}{c}\text { No. of animals receiving FG } \\
3 \text { d after nigral implant }\end{array}$ & 4 & $3^{*}$ & 4 \\
$\begin{array}{c}\text { No. of animals receiving FG } \\
8 \text { d after nigral implant }\end{array}$ & 4 & 4 & 4 \\
$\begin{array}{c}\text { No. of animals receiving FG } \\
13 \text { d after nigral implant }\end{array}$ & 4 & 4 & 4 \\
\hline
\end{tabular}

$\overline{\text { Bridge grafts were implanted } 2 \mathrm{~d} \text { before nigral implantation. Animals were killed } 2 \mathrm{~d}}$ after fluorogold (FG) injection. * indicates loss of an animal during the surgical procedure.

the incisor bar $2.3 \mathrm{~mm}$ below the interaural line. To assess the proportion of implanted nigral neurons whose neurites had reached striatum, $0.4 \mu \mathrm{l}$ of a $2 \%$ solution of fluorogold (Schmued and Fallon, 1986) in distilled water was injected over $1 \mathrm{~min}$ at the following striatal coordinates: A, 0.6 $\mathrm{mm}$; L, $2.4 \mathrm{~mm}$ (from bregma); $\mathrm{V},-4.5 \mathrm{~mm}$ (from dura mater). The needle of the $1 \mathrm{ml}$ glass syringe (Hamilton) was left in place for $5 \mathrm{~min}$ before gentle withdrawal. The experimental design is depicted in Table 2 .

Tissue processing. After either 5, 10, or $15 \mathrm{~d}$ after nigral graft, animals were perfused, and their brains were processed as described for the cograft experiment. Immunohistochemistry was first performed on freefloating $50 \mu \mathrm{m}$ parasagittal sections (one in four) for $\mathrm{TH}$, using a rabbit polyclonal antibody (Institut Jacques Boy) amplified by biotin anti-rabbit (Dako) and streptavidin peroxidase (Vector Laboratories, Burlingame, CA) and revealed by the diaminobenzidine-peroxidase method. Total counts of TH-positive neurons within both nigral grafts were made, and fiber density within the bridge graft track was calculated at a distance of $1.5 \mathrm{~mm}$ from the anterior margin of each nigral graft; the total number of fibers crossing a line perpendicular to the axis of the bridge was obtained and divided by the width of the graft at that point and again by $50 \mathrm{~mm}$. An additional series of sections (one in four) were stained using a mouse monoclonal antibody against TH (Boehringer Mannheim), followed by biotinylated anti-mouse antibodies and streptavidin conjugated to rhodamine (Dako) for fluorescence analysis of the proportion of TH neurons that also contained fluorogold, retrogradely transported from the striatal injection site.

\section{Statistical treatment}

All data were analyzed by multifactorial ANOVA using the Genstat 5.3 statistical package (AFRC Experimental Research Station, Rothampsted, UK) and SigmaStat (Jandel Scientific, San Rafael, CA), using the appropriate post hoc tests for multiple comparisons to confirm the locus of significant mean effects and interactions.

Animal procedures and care were in accordance with the United Kingdom Animal (scientific procedures) Act of 1986.

\section{RESULTS}

\section{GDNF production by SCTM41 and transfected clones}

Individual clones were expanded and analyzed for GDNF secretion using an ELISA assay. The analysis was conducted by collecting medium from $25 \mathrm{~cm}^{2}$ flasks while the cells were dividing unhindered by confluence. Four milliliters of medium were added to each flask and removed after $48 \mathrm{hr}$ incubation. Medium from clone 2 was found, by ELISA assay, to contain $46 \pm 4.6 \mathrm{ng} / \mathrm{ml}$ GDNF. Each flask contained $\sim 10^{6}$ cells; the secretion rate of GDNF by this clone is therefore $\sim 92 \mathrm{ng} / 10^{6}$ cells/d. The parent cell line SCTM41 was also assayed and found to secrete no detectable levels of GDNF.

\section{Expression of Schwann cell markers by SCTM41}

SCTM41 were stained for the expression of LNGFR, GAP-43, S100 laminin, and Thy1.1. Of these markers, SCTM41 were found to strongly express S100, GAP-43, and laminin. LNGFR expression was marginal, only slighter stronger than background staining. SCTM41 do not express Thy1.1. This expression pattern is consistent with a Schwann cell-like phenotype. 
A. Number of TH immunoreactive neurones on PLL or on Schwann cells

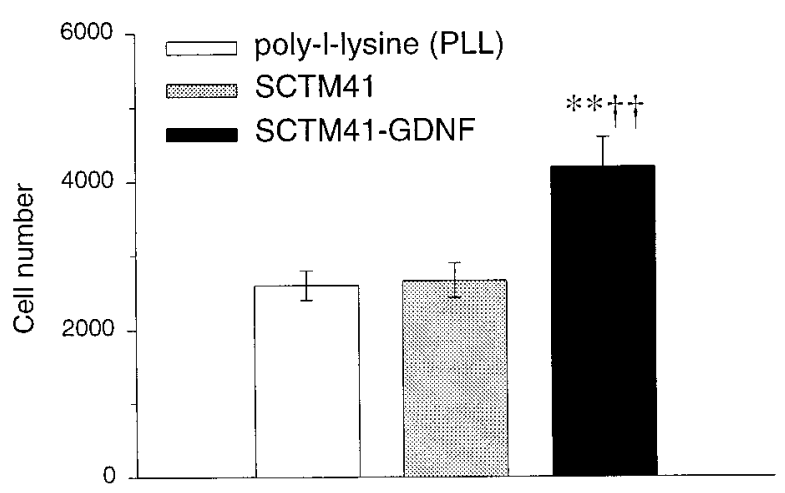

\section{B. Length of TH-immunoreactive neurites on PLL} or on Schwann cells

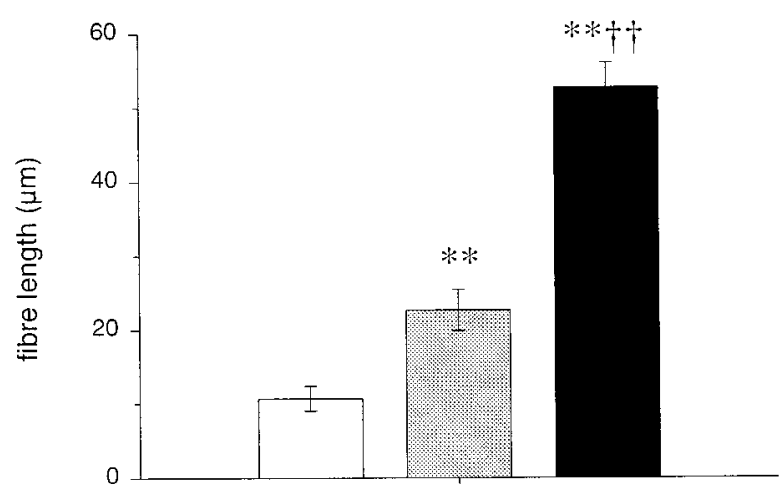

Figure 2. The effects on TH-immunoreactive neuronal survival $(A)$ and neurite length $(B)$ of plating a suspension of E14 ventral mesencephalic cells on poly-L-lysine, SCTM41 cells, and SCTM41 GDNF cells. ${ }^{*} p<<$ 0.01 , significantly different from poly-L-lysine group; $\dagger \nmid p<0.01$, significantly different from untransfected SCTM41 group.

\section{Coculture experiments of dopaminergic neurons with the Schwann cell lines}

To assess the survival and growth potential of dopaminergic neurons in contact with the GDNF-transfected cell line, an in vitro monolayer assay was used. E14 VM was plated onto three different substrate types: poly-L-lysine, SCTM41, or SCTM41 GDNF cells. The $\sim 10^{5}$ SCTM41 GDNF cells in each well will have secreted $\sim 9 \mathrm{ng}$ of GDNF in $24 \mathrm{hr}$ into a medium volume of $0.25 \mathrm{ml}$, giving an eventual concentration of $\sim 36 \mathrm{ng} / \mathrm{ml}$. The medium will very rapidly, therefore, have attained the $\mathrm{ED}_{50}$ dose for GDNF on nigral dopaminergic neurons of $20 \mathrm{pg} / \mathrm{ml}$ (Fawcett et al., 1995; Pong et al., 1997). After $1 \mathrm{~d}$ in culture, cells were fixed and stained for TH expression. TH-positive neuron counts were obtained for a total of 34 coverslips performed over three separate determinations. The largest number of TH-positive neurons was found with the GDNF-producing variant of SCTM41 (4162 \pm 390$)$ compared with both the non-GDNF-producing parent and control substrates $(2628 \pm 251$ and $2597 \pm 225$, respectively) (Fig. $2 A$ ). To determine the precise effect of each substrate on TH-positive cell numbers, ANOVA was performed on the data. This revealed a strong effect of substrate on the likelihood of observing a TH-positive neuronal phenotype within the culture $\left(F_{(2,32)}=9.02 ; p<0.001\right)$. A post hoc Newman-Keuls

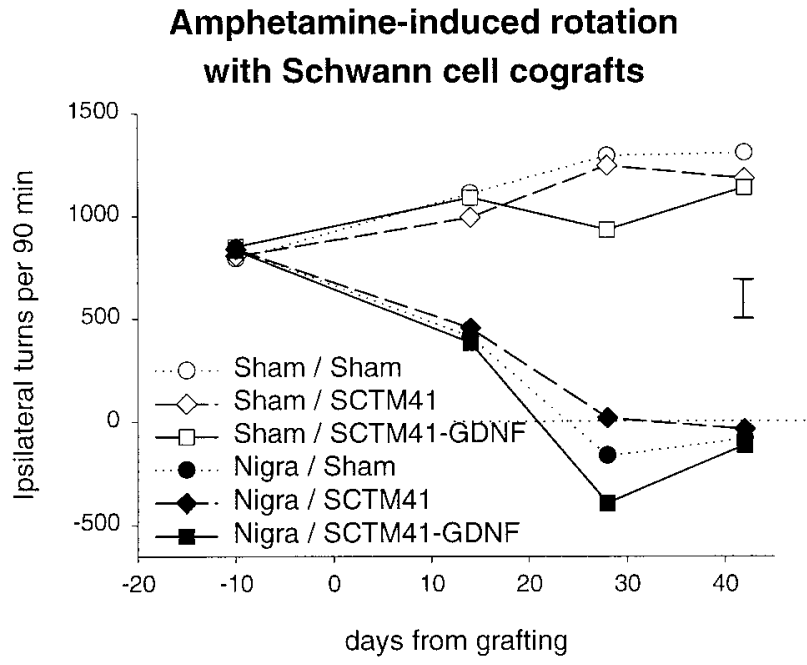

Figure 3. Amphetamine-induced rotation of animals with various combinations of embryonic mesencephalic and cograft to the striatum. Animals with sham mesencephalic grafts show no improvement, even in the presence of GDNF. All the animals with mesencephalic grafts show a steady improvement over $30 \mathrm{~d}$, and there were no significant differences between these three groups. Error bar indicates SEM.

test revealed that GDNF-secreting Schwann cells significantly increase the likelihood of observing TH-positive neurons within the culture compared with either the parent cell monolayer or the control substrate $(p<0.01)$.

Process lengths of dopaminergic neurons were measured in a random selection of cells. TH-positive fibers extended up to five times as far on the GDNF-secreting cells $(52.80 \pm 3.54 \mathrm{~mm})$ compared with control $(10.73 \pm 1.81 \mathrm{~mm})$. The parent cell line allowed $22.69 \pm 2.82 \mathrm{~mm}$ average fiber extension (Fig. $2 B$ ). A one-factor ANOVA revealed a very strong effect of substrate on fiber length $\left(F_{(2,144)}=64.25 ; p<0.001\right)$. A post hoc NewmanKeuls test revealed that the parent (non-GDNF-secreting) Schwann cell line had a significant growth-promoting effect compared with control $(p<0.01)$. However, the GDNF-secreting Schwann cells were found to be even more growth supportive than the nonsecreting cells $(p<0.01)$.

\section{Cograft experiment (adjacent mesencephalic and Schwann cell grafts to the striatum)}

\section{Rotation}

All groups of animals exhibited similar high rates of amphetamine-induced rotation before transplantation. Those that received no nigral component of the cograft remained highly asymmetrical over the 6 weeks after graft surgery. The animals in receipt of nigral grafts all exhibited complete restoration of symmetry and subsequent "overcompensation" as assessed by amphetamine-induced rotation (Fig. 3). These three groups differed significantly over time from the "sham nigra" groups (tests $\times$ group, $F_{(3,90)}=7.71 ; p<0.001$ ). All experimental groups with nigral grafts displayed the same rate of recovery, regardless of either GDNF production or the presence of Schwann cells (tests $\times$ group $\times$ cells, $F_{(6,90)}=0.11$; tests $\times$ cells, $F_{(6,90)}=0.97$; both not significant). The control grafts contained sufficient surviving dopaminergic neurons to fully correct amphetamineinduced rotation, so no extra effect from the additional surviving cells in the GDNF group would be expected. 

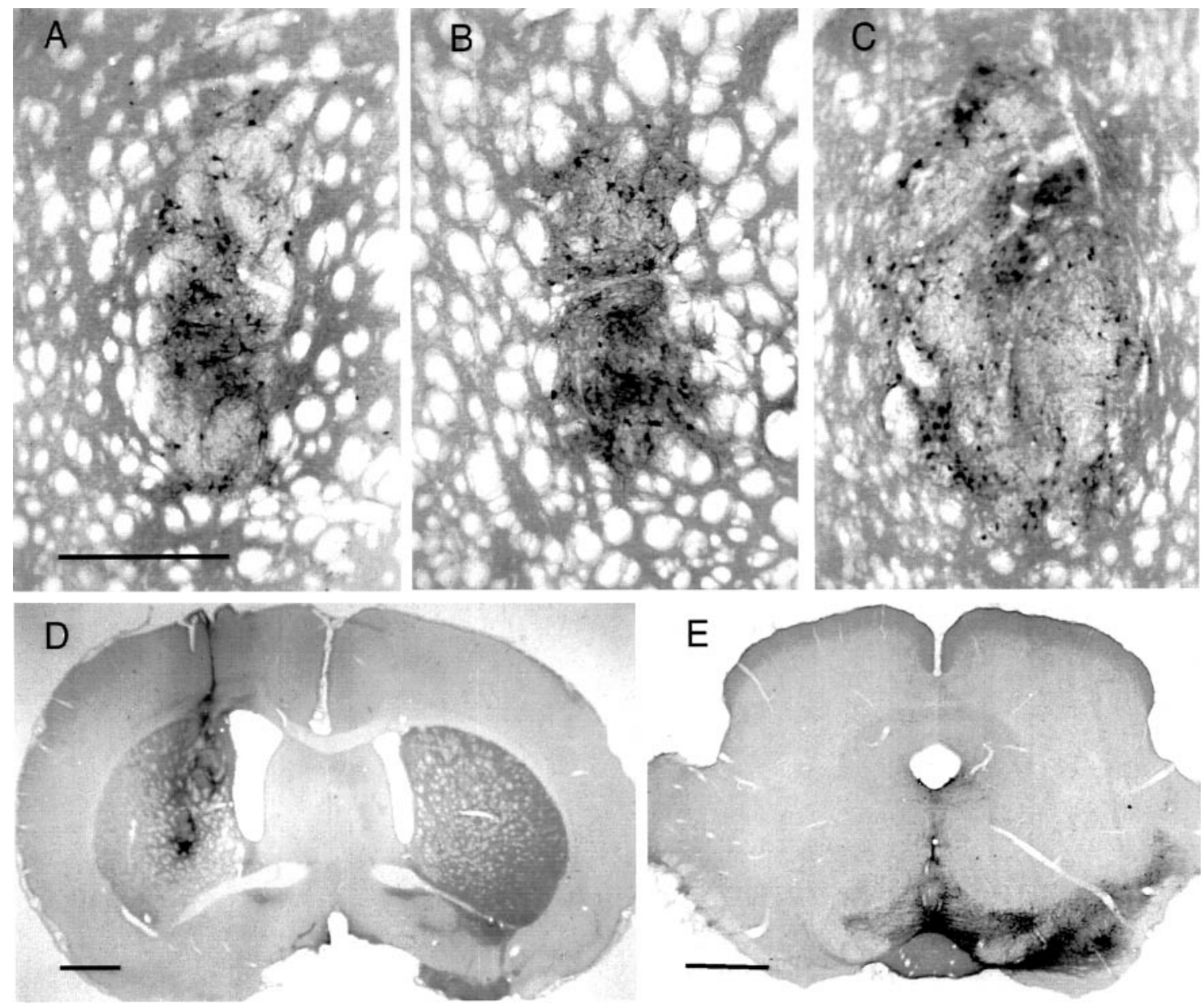

Figure 4. Grafts of E14 VM to the 6-OHDA-lesioned animals 6 weeks after transplantation, immunostained for TH. A sham graft was transplanted nearby in $A$, SCTM41 cells in $B$, and SCTM41 GDNF cells in $C$. $D$ is a low-power shot of an SCTM41 GDNF cotransplanted mesencephalic graft. $E$ shows that all the TH-immunoreactive neurons in the substantia nigra on one side are removed by the 6-OHDA lesion. Scale bars, $500 \mu \mathrm{m}$.

\section{TH histology}

In accordance with the pretransplantation and posttransplantation rotation data, all animals not in receipt of a nigral graft showed a virtually complete absence of TH-positive neurons in substantia nigra ipsilateral to the 6-OHDA lesion, accompanied by an absence of TH staining in the ipsilateral striatum, irrespective of any Schwann cell graft. In all animals that received nigral transplants, well defined healthy grafts were visible. These neurons were observed to have put out neurites into the host striatum, which had grown for up to $2 \mathrm{~mm}$ from the graft-host interface (Fig. 4). There was great variation in the size of grafts; those that were cografted with GDNF-secreting Schwann cells were larger and contained more dopaminergic neurons than the other groups. In some cases, within this group, the two grafts were so large that they both appeared in the same coronal section, despite their oblique placement.

\section{Cell counts}

The number of TH-positive neurons surviving in the grafts was approximately three times higher in the presence of the GDNFsecreting Schwann cell line than in the presence of the control Schwann cells or in control animals with sham grafts (cells, $F_{(2,15)}$ $=6.68 ; p<0.01)($ Fig. $5 A)$. Mean total TH-positive cell number in both deposits was 1390 for control grafts, 1482 for cografts with
SCTM cells, and 4158 for the GDNF-transfected cells. Because one mesencephalic fragment was suspended in $5 \mu \mathrm{l}$ and each of the two grafts contained $2.5 \mu \mathrm{l}$ of suspension, a total of one mesencephalon was injected into each host. Because each mesencephalon would contain $\sim 47,000$ dopaminergic neurons, overall survival of TH neurons was $3 \%$ in the control group, $3.2 \%$ in the cografts with untransfected cells, and $8.9 \%$ in cografts with GDNF transfected cells.

\section{Cell body volume}

Cotransplantation with Schwann cells also affected the size of the somata of the surviving TH cells (Fig. 5B). The effect of cografted cells on cell body volume was highly significant (cells, $\left.F_{(2,15)}=7.35 ; p=0.006\right)$.

\section{Fiber outgrowth}

Estimates of fiber density at different distances (as at subsequent rungs of ladders) from the graft-host border are shown in Figure 6. The data are segregated according to graft site (medial and lateral) and according to direction of outgrowth relative to the Schwann cell cograft (proximal and distal). In all groups of animals, fiber density declined with distance from the graft. None of the interactions of direction with any other factor was significant, suggesting that there were no direction-specific effects on 
A. Number of TH immunoreactive neurones in nigral grafts with Schwann cell cografts

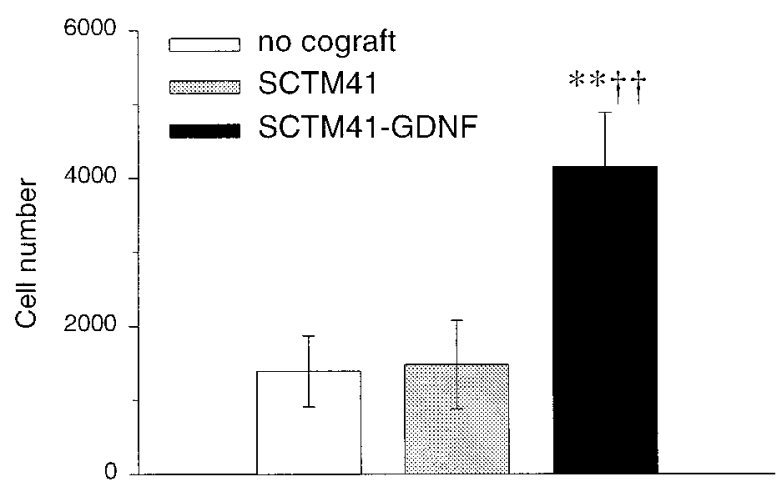

B. Size of TH-immunoreactive cells in nigral grafts

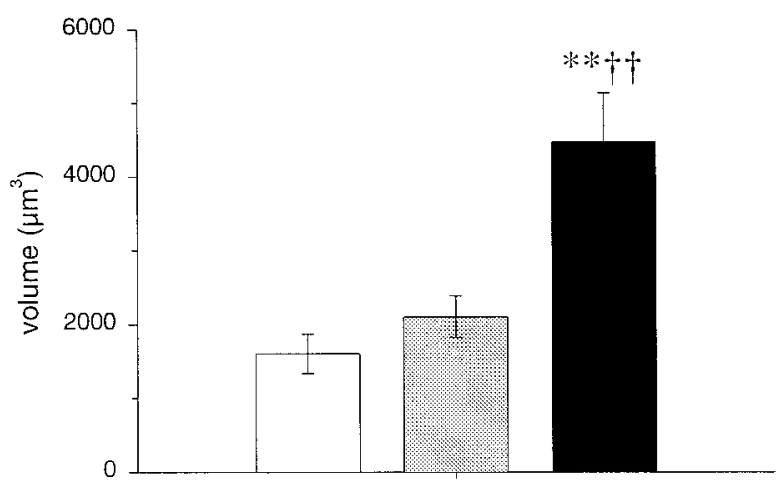

Figure 5. A, The numbers of surviving TH-immunoreactive neurons in embyronic mesencephalic grafts to the striatum, with a nearby sham, SCTM41, or SCTM41 GDNF graft. The SCTM41 cells have no survivalpromoting effect, but the GDNF cells increase survival approximately threefold. $B$, Estimated cell body volume of surviving THimmunoreactive neurons. The presence of GDNF-secreting cells more than doubles the cell volume. Error bars indicate SEM. ${ }^{* *} p<0.01$, significantly different from no cograft group; $\dagger p<0.01$, significantly different from untransfected SCTM41 cograft group.

the grafts. There were, however, two significant effects of Schwann cell cograft on fiber density. The first was an effect of the type of cograft on the overall density of fiber outgrowth. On examination of Figure 6, it is apparent that the GDNF-secreting cells greatly increased fiber density over both the nonsecreting Schwann cells and the control grafts. At the graft-host border, the nontransfected cograft group does not differ from control values (as revealed by post hoc analysis); the GDNF-transfected group does differ significantly, however $(p<0.01)$. Moreover, this density increase, by a factor of approximately three, is the same as the factor by which cell numbers were increased by the presence of GDNF cells. GDNF did not, therefore, increase the number of neurites per neuron. The second effect of the Schwann cell cografts was on the gradient of the decline in density with distance from the graft; both cell lines caused a reduction in the gradient, indicating that the cografts promoted the outgrowth of fibers from the graft. Outgrowth was no greater on the side of the nigral grafts adjacent to the SCTM41 or SCTM41 GDNF cells, suggesting that neither SCTM41 nor GDNF has a chemoattractant effect on dopaminergic neurons.
TH-immunoreactive neurite outgrowth from nigral grafts

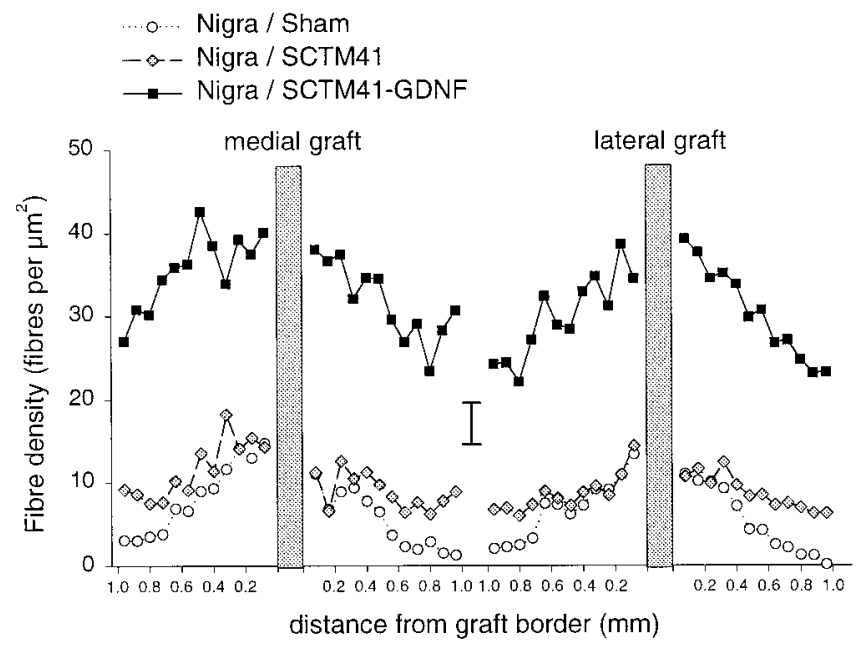

Figure 6. TH-immunoreactive fiber density measured at various distances from the border of embryonic mesencephalic grafts. Both medial and lateral grafts are shown. In between these was a sham graft, or a graft of SCTM41 or SCTM41 GDNF cells. Fiber density declines with distance from the graft in all cases, but the fiber density is much higher in grafts with access to GDNF. There is no significant difference in the fiber densities or the rate of decline of fiber density on the sides of the grafts adjacent to the Schwann cell grafts relative to the other sides of the grafts, so there is no evidence that GDNF is having a chemoattractive effect.

\section{Bridge graft experiment (orthotopic mesencephalic graft with Schwann bridge to the striatum)}

This experiment was designed to assess the effectiveness of SCTM41 cells as a bridge graft promoting axon growth from homotopically placed nigral grafts toward the striatum and the effects of GDNF secretion by the bridge graft cells. A bridge of SCTM cells was placed along a line from nigra to striatum, and $2 \mathrm{~d}$ later, a graft of embryonic nigra was placed within the lesioned nigra, adjacent to the caudal end of the bridge graft.

\section{Histology of the dopaminergic grafts}

To assess survival of the intranigral grafts, TH-diaminobenzidine histology was performed on $50 \mathrm{~mm}$ frozen parasagittal sections (frequency; 1:4). Grafts appeared large and healthy in most animals, containing many TH-positive neurons that could be seen to extend fibers a short distance into the adjacent host neuropil. Easily distinguishable from the grafted neurons by their size, morphology, and position (Fig. 7), very few intrinsic dopaminergic neurons spared by the 6-OHDA lesions could be seen in some cases lying rostral and dorsal to the graft.

\section{Cell counts: TH-positive cells within the grafts}

An Abercrombie (1946) corrected mean determination of THpositive neurons present within the grafted site for each subgroup is presented graphically in Figure 8. A two-factor ANOVA was performed on these data and revealed a strong effect of survival time on cell number $\left(F_{(2,25)}=7.09 ; p<0.01\right)$ and no overall effect of bridge graft material $\left(F_{(2,25)}=2.51 ; p>0.05\right)$, but there was an interaction between time and bridge material $\left(F_{(4,25)}=3.57 ; p<\right.$ $0.05)$. The basis for these effects was revealed by a posteriori analysis to be the increased survival of nigral grafts with SCTM41 GDNF cells at $15 \mathrm{~d}$ survival time. This group was significantly different from the GDNF bridge groups at 5 and $10 \mathrm{~d}$ survival ( $p<0.01$ for both cases). Moreover, the GDNF bridge 
Figure 7. $a$ shows a TH immunostained section from an animal that received a graft of embryonic mesencephalon to the region of a 6-OHDAlesioned substantia nigra $15 \mathrm{~d}$ before fixation, together with a bridge graft of SCTM41 GDNF cells. The less than sign indicates the graft of embryonic dopaminergic neurons, and the asterisk indicates the needle track through which it was introduced. The bridge graft, which contains some dopaminergic axons, comes into the plane of the section just caudal to the striatum and is marked with a black arrow. The white arrow marks a puff of dopaminergic terminals where an axon has left the bridge graft to innervate the striatum. Scale bar, $500 \mu \mathrm{m}$. $b$ and $c$ show, respectively, fluorogold and $\mathrm{TH}$ fluorescence in a neuron within the mesencephalic graft. $d$ shows a highpower shot of TH-immunoreactive axons growing in the environment of an SCTM41 GDNF bridge graft. Scale bar, $50 \mu \mathrm{m}$.
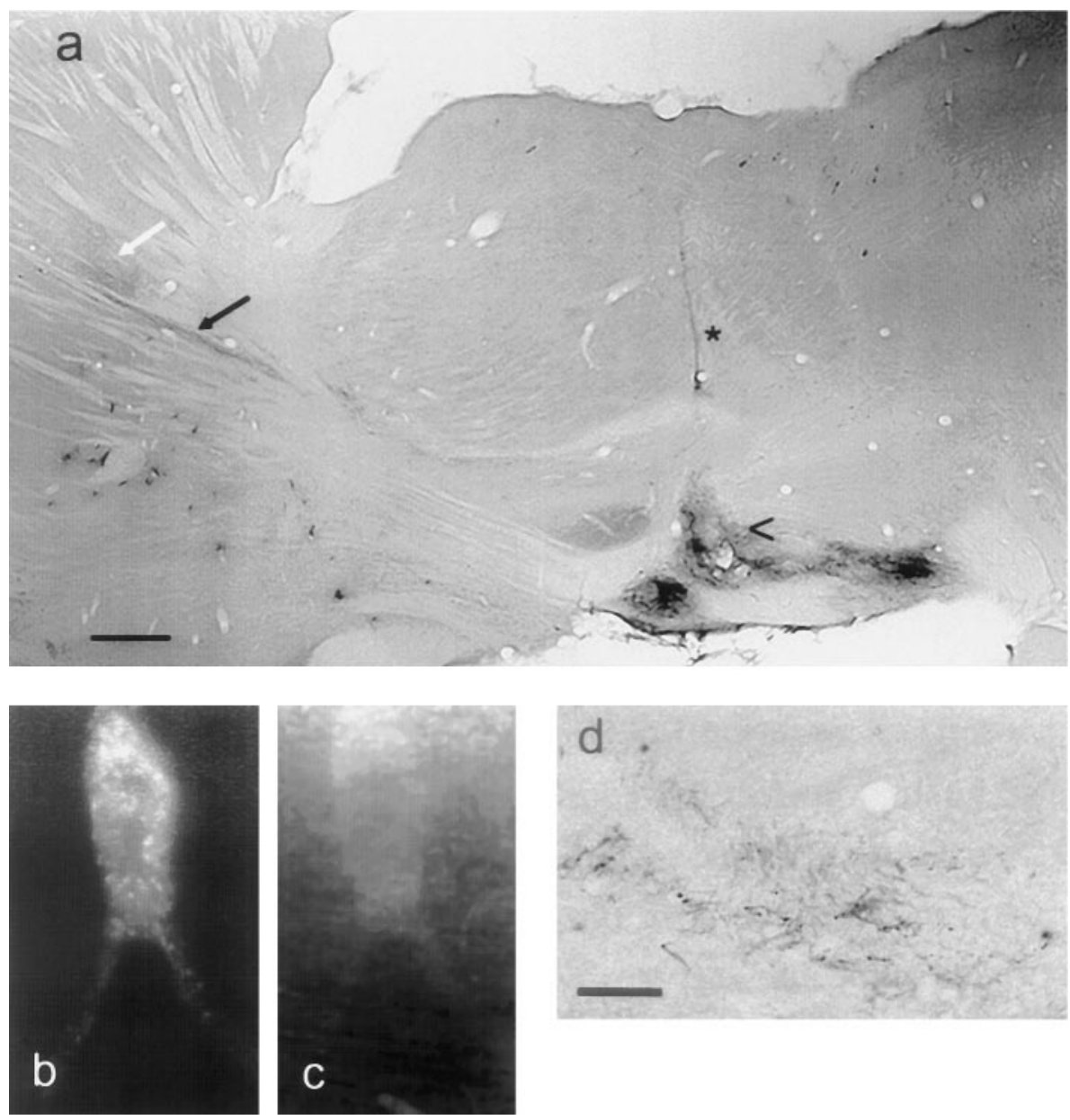

group was significantly different from the other bridge groups at the $15 \mathrm{~d}$ survival time $(p<0.01)$. At $15 \mathrm{~d}$, the overall survival of TH neurons through the grafting procedure was $4.9 \%$ in the sham graft control group, $4.2 \%$ in the group with untransfected SCTM41 cells, and $10.4 \%$ in the cografts with GDNF-transfected cells.

\section{Cell counts: TH-positive cells of intrinsic nigra}

To assess the effects of either GDNF or time on the expression of TH by intrinsic nigra that had survived the 6-OHDA insult, these cells were counted. There were no significant differences between any group at any of the time points.

\section{Dopaminergic neurite outgrowth}

TH immunostaining with diaminobenzidine as the chromogen was used to assess fiber growth. TH-positive fibers were seen to leave the nigral graft site and were clearly visible within the constraints of the bridge graft coursing their way toward the striatum (Fig. 7). The number of fibers crossing an arbitrary line running perpendicular to the axis of the bridge graft were counted at a distance of $1.5 \mathrm{~mm}$ from the nigral graft. This value was then converted into a measure of fiber density (axons/100 $\mu \mathrm{m}^{2}$ ) following an estimation of bridge graft diameter. A twofactor ANOVA on these data revealed a strong effect of bridge graft material on fiber density within the bridge $\left(F_{(2,25)}=23.908\right.$; $p<0.001)$ but no effect of time and no interaction between time and substrate. Therefore, results were pooled across time and are graphically expressed in Figure $9 A$. Post hoc Newman-Keuls tests

revealed significant differences between all bridge graft types: SCTM41 GDNF $>$ SCTM41 $>$ vehicle $(p<0.01$ in all cases).

Cresyl violet-stained sections were examined to obtain actual bridge graft diameter values, which were subsequently used to generate values of total $\mathrm{TH}$-positive fibers within the bridge (assuming the bridge graft to be a uniform cylinder) (Brecknell et al., 1996a,b). Again, two-factor ANOVA revealed an effect of bridge graft material on the number of generated fibers $\left(F_{(2,25)}=\right.$ 6.08; $p<0.01)$ but no effect of time and no interactions. Results were therefore pooled across time and are depicted graphically in Figure 9B. Post hoc Newman-Keuls tests revealed that both SCTM41 and SCTM41 GDNF gave rise to greater fiber numbers than vehicle ( $p<0.05$ and 0.01 , respectively) but did not differ significantly from each other.

\section{Fluorogold and TH double-labeled cell counts}

To assess the growth of axons from the nigral grafts to their striatal target, fluorogold was injected into the striatum $2 \mathrm{~d}$ before the termination of the experiment. Double-labeled cells with fluorogold incorporation and $\mathrm{TH}$ immunoreactivity were counted within the graft site (Fig. $7 b, c$ ). Few unlesioned intrinsic nigral neurons were identifiable within sections, anatomically distinctive from extrinsic neurons and therefore not counted. The Abercrombie (1946) corrected determinations of mean numbers of double-labeled grafted cells are presented graphically in Figure 10. Two-way ANOVA revealed an effect of time on the number of double-labeled neurons within the graft $\left(F_{(2,26)}=4.27 ; p<0.05\right)$ and a significant interaction between time and the nature of the 
Number of TH immunoreactive neurones in nigral grafts with Schwann cell cografts

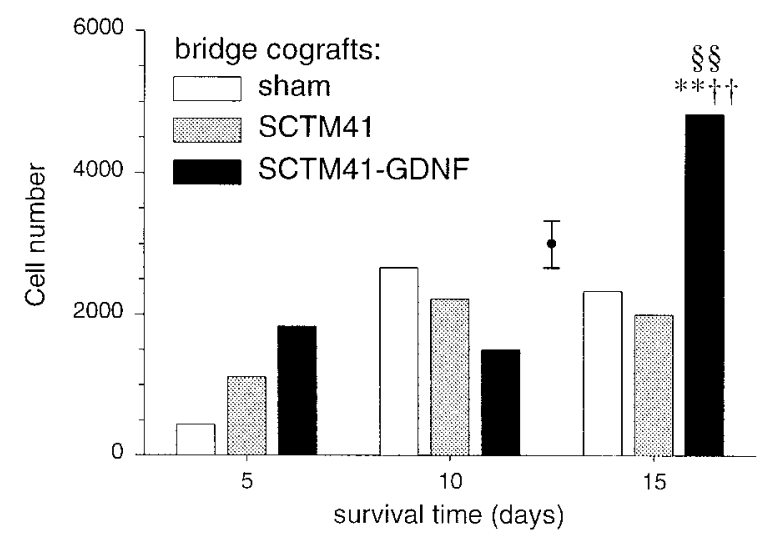

Figure 8. The effects of a bridge graft on the survival of $\mathrm{TH}-$ immunoreactive neurons in transplants placed in the region of the substantia nigra. The presence of GDNF had a strong survival-promoting effect but only when assayed at $15 \mathrm{~d}$. Error bar indicates SEM. ${ }^{* *} p<0.01$, significantly different from sham cograft group; $\dagger \uparrow p<0.01$, significantly different from untransfected SCTM41 cograft group; $\$ \$ p<0.01$, significantly different from the same group at earlier survival times.

\section{A. Density of TH-immunoreactive axons in bridge grafts}

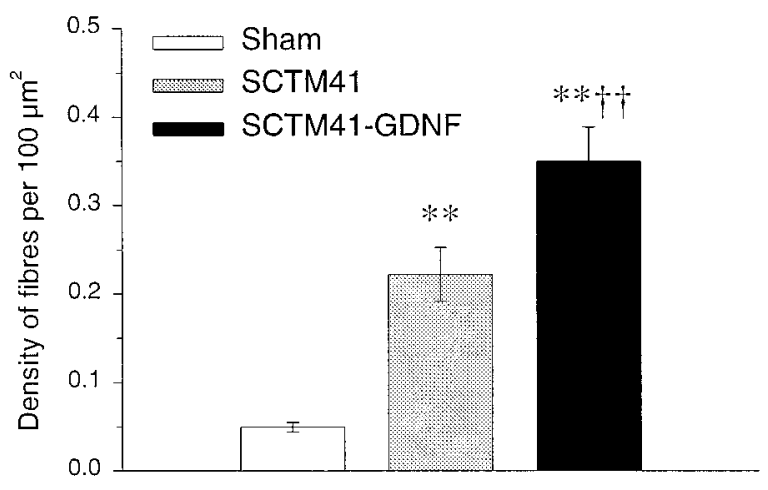

B. Number of $\mathrm{TH}$-immunoreactive axons in bridge grafts

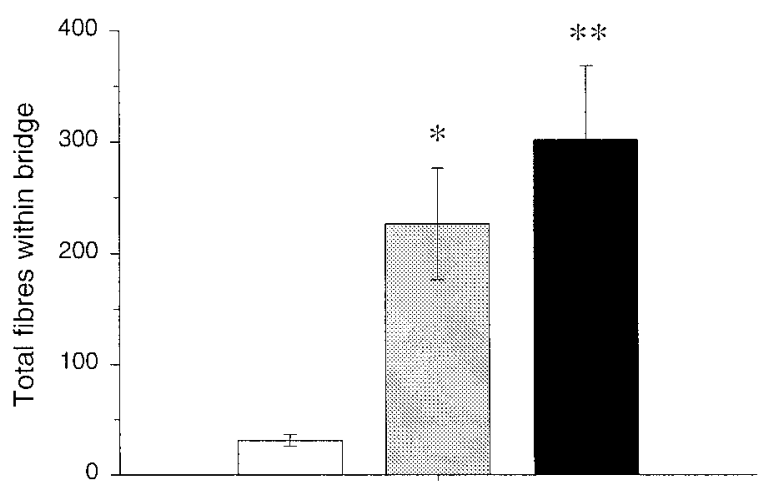

Figure 9. The density $(A)$ and overall number $(B)$ of THimmunoreactive axons in bridge grafts, measured $15 \mathrm{~d}$ after operation. SCTM41 cells promoted axon growth relative to a sham graft, and SCTM41 GDNF cells were significantly better than the parent cell line. ${ }^{*} p<0.05$ and ${ }^{* *} p<0.01$, significantly different from sham graft group; $\dagger p<0.01$, significantly different from SCTM41 bridge graft group.
Number of TH and fluorogold double-labelled neurones in nigral grafts with Schwann cell cografts

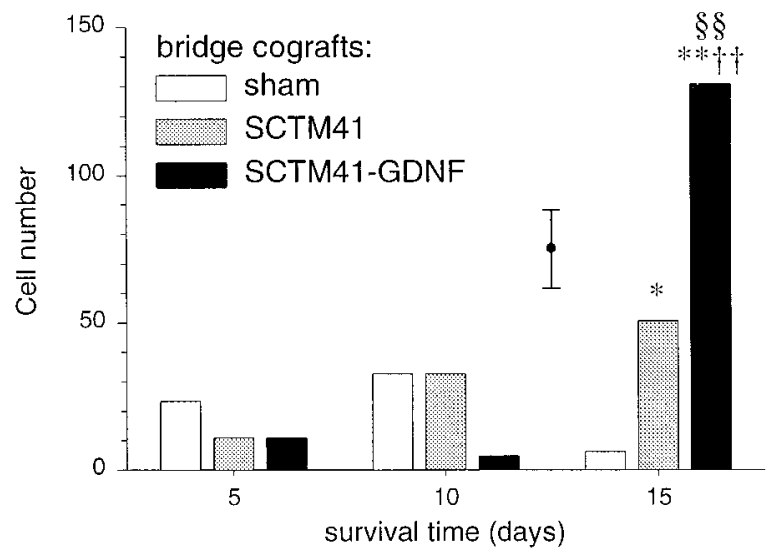

Figure 10. Retrograde labeling from the striatum of $\mathrm{TH}-$ immunoreactive neurons in grafts of E14 mesencephalic tissue placed in the substantia nigra, with a bridge graft between the nigral graft and the striatum. There was no significant difference between the groups, except that at $15 \mathrm{~d}$ greater connectivity with the striatum could be seen in grafts whose axons were growing through GDNF-secreting cells. ${ }^{*} p<0.05$ and ${ }^{* *} p<0.01$, significantly different from sham group; $\dagger p<0.01$, significantly different from SCTM41 bridge graft group; $\$ \S p<0.01$, significantly different from the same group at earlier survival times.

bridge graft substrate $\left(F_{(4,26)}=4.24 ; p<0.01\right)$. Post hoc Newman-Keuls tests revealed significant differences between the number of double-labeled cells within GDNF-secreting bridgegrafted animals at $15 \mathrm{~d}$ compared with the other bridge substrates [SCTM41 GDNF $>$ SCTM41 $(p<0.01)>$ vehicle $(p<0.05)]$. Animals within this group were also significantly different from GDNF-secreting bridge-grafted animals at earlier survival times $(p<0.01$ for both cases).

\section{DISCUSSION}

The two major problems in the use of embryonic mesencephalic grafts for the treatment of Parkinson's disease are the poor survival of grafted neurons and their inability to grow axons through the host CNS to their appropriate targets. We show here that the combination of Schwann cells and GDNF goes some way toward solving these problems. When dissociated embryonic mesencephalon was plated in vitro onto the SCTM41 Schwann cell line in untransfected and GDNF-transfected forms, dopaminergic neuronal survival was greater on GDNF cells than on the parent line or poly-L-lysine. Axon growth from the dopaminergic neurons was greater on SCTM41 cells than on poly-L-lysine and greater still on GDNF-transfected cells (Fig. 2). To assay for survival-promoting and axon growth-promoting effects in vivo, SCTM41 cells were grafted adjacent to deposits of fetal mesencephalon in the striatum of animals with 6-OHDA lesions of the substantia nigra. Nontransfected SCTM41 cells had no more effect on survival than sham surgery, but GDNF-transfected cells greatly increased dopaminergic neuronal survival, cell body size, and axon growth; however, this increased axon growth was not directed preferentially toward the GDNF-secreting cells (Figs. 4-6). Nontransfected and GDNF-transfected SCTM41 cells were then assessed for their ability to provide a bridge of axon growth-permissive material between fetal mesencephalic grafts placed orthotopically in the 6-OHDA-lesioned substantia nigra and their target in the striatum. A significant number of axons 
grew through untransfected SCTM41 cells to the striatum, but the density of growth and the number of graft dopaminergic neurons that could be back labeled from the striatum was increased in GDNF-transfected cells (Figs. 7, 9, 10). The presence of a bridge graft of GDNF-transfected cells also increased the number of surviving dopaminergic neurons in the grafts (Fig. 8).

\section{Secretion of trophic factors by Schwann and SCTM41 cells}

Schwann cells are reported to secrete several trophic factors under some circumstances. Little trophic factor secretion is seen except in degenerating and regenerating peripheral nerves, and in Schwann cells in culture that are not in contact with axons. Under these circumstances, Schwann cells may produce NGF, BDNF, CNTF, GDNF, and other factors (Heumann et al., 1987; Meyer et al., 1992; Henderson et al., 1994; Lee et al., 1995). Untransfected SCTM41 cells do not produce quantities of GDNF, BDNF, or NT3 that are detectable by Western blot or two-site ELISA. Production of trophic factors by Schwann cells or peripheral nerve grafts implanted into the CNS has not been studied, but grafted cells downregulate c-jun and GAP-43 (Vaudano et al., 1995, 1996), two molecules associated with activation, which in turn is also associated with trophic factor production. Thus, it is possible that grafted cells produce little trophic factor. It is therefore likely that, like the SCTM41 line, primary Schwann cells will have to be modified if they are to secrete trophic factors when implanted into the CNS. In other respects, the SCTM41 line also closely resembles primary Schwann cells in that they express S100, GAP-43, laminin, and low levels of LNGFR.

\section{Effects of SCTM41 and SCTM41 GDNF cells on dopaminergic neuronal survival}

Untransfected SCTM41 cells had no effect on dopaminergic neuronal survival in vitro, and deposits of these cells implanted near embryonic mesencephalic grafts had no effect on dopaminergic neuronal survival in vivo. This is consistent with the absence of trophic factor production in the parent cell line. The GDNF-producing line, however, increased dopaminergic neuronal survival both in vitro and in vivo. When cocultured with GDNF-secreting cells, dopaminergic neuronal survival was increased by $158 \%$ over the first $24 \mathrm{hr}$, whereas grafts of GDNFsecreting cells placed adjacent to grafts of embryonic mesencephalic grafts increased dopaminergic survival approximately three times after 6 weeks in one experiment and approximately two times after $15 \mathrm{~d}$ in the other. Effects of GDNF on the survival of both embryonic and adult mesencephalic dopaminergic neurons have been reported by several previous authors (Engele and Franke, 1996; Rosenblad et al., 1996; Sinclair et al., 1996; Wang et al., 1996; Winkler et al., 1996; Tseng et al., 1997). An unexpected feature of our experiments was that grafted dopaminergic neuronal survival was only increased relative to controls at time points longer that $10 \mathrm{~d}$. We saw an effect on survival in vitro within $24 \mathrm{hr}$, and much of the cell death in grafted dopaminergic neurons occurs within the first days after implantation, possibly because of damage sustained soon after transplantation (Barker et al., 1996). Thus, our cografting strategy probably did not deliver effective doses of GDNF sufficiently rapidly to prevent the first wave of cell death. It is likely, therefore, that the GDNF secreted by the cografts of SCTM GDNF cells was primarily effective in improving the survival and enhancing the expression of $\mathrm{TH}$ in neurons that had survived the first wave of cell death in the day or so immediately after implantation. The quantities of
GDNF secreted by our grafts ( $\sim 90 \mathrm{ng} /$ day) were much lower that in previous experiments in which daily injections of up to $1000 \mathrm{ng}$ were given. Although in those experiments $1000 \mathrm{ng} / \mathrm{d}$ had a greater effect on dopaminergic neuronal survival than $500 \mathrm{ng} / \mathrm{d}$ (Sinclair et al., 1996), these are massive doses compared with an $\mathrm{ED}_{50}$ of $20 \mathrm{pg} / \mathrm{ml}$ on dopaminergic neurons in culture(Pong et al., 1997), and the amount secreted by our grafts should have brought the nearby nigral grafts up to an effective dose sufficient for a maximal effect within a short time, particularly in view of the ability of substantia nigra neurons to retain and transport GDNF (Lapchak et al., 1997).

\section{Axon growth from grafted dopaminergic neurons}

In vitro, dopaminergic axonal growth was greater on SCTM cells than on poly-L-lysine and greater again on GDNF-transfected SCTM cells. We examined two types of axon growth in vivo: that from mesencephalic grafts placed in the striatum through host striatal tissue, and that from mesencephalic grafts place in the nigra through bridge grafts of SCTM cells. Growth into striatum from grafts in the striatum was affected by both the presence of SCTM cells and the presence of GDNF. The density of dopaminergic processes leaving the grafts and entering the striatum was unaffected relative to control by the presence of SCTM cells but was considerably increased by cografts of SCTM GDNF cells. However, the number of processes increased by a factor of three over controls, and the number of surviving cells also increased by a factor of three in the presence of GDNF-secreting cells, so there was no increase in the number of processes per neuron. The decline in process density over distance was decreased by the presence of both transfected and untransfected SCTM cells. We saw no evidence that neurites were growing preferentially toward SCTM or SCTM GDNF grafts, so the effect was trophic rather than tropic.

A major objective of this work was to enhance the connectivity with the striatum of mesencephalic grafts placed in the substantia nigra. No axons grow from rat embryonic mesencephalic grafts placed in the substantia nigra to the striatum unless some form of bridge is provided. In a previous study, we used the Schwannoma cell line RN22 as a bridge graft, which, because of its tumorogenicity, had to be irradiated (Brecknell et al., 1996a,b). RN22 cells attracted $\sim 100$ axons from the mesencephalic grafts. Most of these axons were able to leave the graft, enter the host striatum, and produce a reduction in amphetamine-induced rotation. To improve the bridge grafts, we have used a new Schwann cell line, SCTM41, which does not form tumors, and transfected it to secrete GDNF, which is the most potent trophic factor for mesencephalic dopaminergic neurons. Our expectation was that GDNF secretion would improve the survival of grafted neurons, as discussed above, and that axon growth would be enhanced. We found that the untransfected cell line supported the growth of axons from mesencephalic grafts to striatum in greater numbers than the RN22 line we have used before. Moreover, transfection with GDNF further increased the number and density of axons in the grafts. The mean number of axons in the GDNF grafts was $\sim 300$, the largest number being 899 . This is still only a small proportion of the 3-5000 neurons surviving in our grafts, but sufficient to correct most of the behavioral deficits, which requires 110-200 neuronal projections (Brundin et al., 1985; Brecknell et al., 1996a,b). Retrograde tracing with injections of fluorogold confirmed that the dopaminergic axons were derived from grafted neurons. These connections were not seen by retrograde tracing until $10 \mathrm{~d}$ after the neuronal and bridge grafts were 
inserted. Clearly, there is still scope for improving axon recruitment into bridge grafts beyond what we have achieved in these experiments with GDNF transfection. This might be achieved by changes to the surface properties and molecules secreted by Schwann cells, by improving the geometry of the grafting operations, by increasing the axon growth potential of the dopaminergic neurons, and perhaps by adding other trophic factors and larger amounts of GDNF.

Grafts of embryonic mesencephalon have been used with some success to treat human patients with Parkinson's disease, but all these grafts have been placed in the caudate nucleus and putamen. In principle, it should be possible to use Schwann cellderived bridge grafts to allow grafts placed in the substantia nigra to connect to these basal ganglia, but because of the large size of these structures in human brain, several tracks would be required to distribute the axons throughout the target structures.

\section{REFERENCES}

Abercrombie M (1946) Estimation of the nuclear population from microtome sections. Anat Rec 94:239-247.

Aguayo AJ, Bjorklund A, Stenevi U, Carlstedt T (1984) Fetal mesencephalic neurons survive and extend long axons across peripheral nervous system grafts inserted into the adult rat striatum. Neurosci Lett 45:53-58.

Annett LE, Martel FL, Rogers DC, Ridley RM, Baker HF, Dunnett SB (1994) Behavioural assessment of the effects of embryonic nigral grafts in marmosets with unilateral 6-OHDA lesions of the nigrostratal pathway. Exp Neurol 125:228-246.

Ard MD, Bunge RP, Bunge MB (1987) Comparison of Schwann cell surface and Schwann cell extracellular matrix as promoters of neurite growth. J Neurocytol 16:539-555.

Barker RA, Dunnett SB, Faissner A, Fawcett JW (1996) The time course of loss of dopaminergic neurons and the gliotic reaction surrounding grafts of embryonic mesencephalon to the striatum. Exp Neurol 141:79-93.

Bixby JL, Lilien J, Reichardt LF (1988) Identification of the major proteins that promote neuronal process outgrowth on Schwann cells in vitro. J Cell Biol 107:353-361.

Björklund A (1991) Neural transplantation: an experimental tool with clinical possibilities. Trends Neurosci 14:319-322.

Björklund A, Stenevi U (1979) Regeneration of monoaminergic and cholinergic neurons in the mammalian central nervous system. Physiol Rev 59:62-100.

Björklund A, Stenevi U, Schmidt RH, Dunnett SB, Gage FH (1983) Intracerebral grafting of neuronal cell suspensions. II. Survival and growth of nigral cell suspensions implanted in different brain sites. Acta Physiol Scand Suppl 120:9-18.

Brecknell JE, Haque NSK, Du JS, Muir E, Fidler PS, Hlavin M-L, Fawcett JW, Dunnett SB (1996a) Functional and anatomical reconstruction of the 6-OHDA lesioned nigrostriatal system of the adult rat. Neuroscience 71:913-915.

Brecknell JE, Du J-S, Muir E, Fidler PS, Hlavin M-L, Dunnett SB, Fawcett JW (1996b) Bridge grafts of FGF-4 secreting schwannoma cells promote functional axonal regeneration in the nigrostriatal pathway of the adult rat. Neuroscience 74:775-784.

Brundin P, Isacson O, Bjorklund A (1985) Monitoring cell viability in suspensions of embryonic CNS tissue and its use as a criterion for intracerebral graft survival. Brain Res 331:251-259.

Bunge RP, Kleitman N, Dean AC (1989) Role of peripheral nerve extracellular matrix in Schwann cell function and in neurite regeneration. Dev Neurosci 11:348-360.

Danielian PS, White R, Hoare SA, Fawell SE, Parker MG (1993) Identification of residues in the estrogen receptor that confer differential sensitivity to estrogen and hydroxytamoxifen. Mol Endocrinol [Abstr] 7:232-240.

David S, Aguayo AJ (1981) Axonal elongation into peripheral nervous system bridges after central nervous system injury in adult rats. Science 241:931-933.

Dunnett SB (1991) Transplantation of embryonic dopamine neurons: what we know from rats. J Neurol 238:65-74.

Dunnett SB, Whishaw IQ, Rogers DC, Jones GH (1987) Dopamine-rich grafts ameliorate whole body asymmetry and sensory neglect but not independent limb use in rats with 6-hydroxydopamine lesions. Brain Res 415:63-78.

Dunnett SB, Rogers DC, Richards SJ (1989) Nigrostriatal reconstruction after 6-OHDA lesions in rats: combination of dopamine rich nigral grafts and nigrostriatal "bridge" grafts. Exp Brain Res 75:523-535.

Engele J, Franke B (1996) Effects of glial cell line-derived neurotrophic factor (GDNF) on dopaminergic neurons require concurrent activation of cAMP-dependent signaling pathways. Cell Tissue Res 286:235-240.

Fawcett JW, Barker RA, Dunnett SB (1995) Survival of embryonic mesencephalic dopaminergic neurones in explant, three-dimensional and monolayer cultures, and the effects of bFGF. Exp Brain Res 106:275-282.

Freed WJ (1991) Substantia nigra grafts and Parkinson's disease: from animal experiments to human therapeutic trials. Restor Neurol Neurosci 3:109-134.

Gage FH, Stenevi U, Carlstedt T, Foster G, Björklund A, Aguayo AJ (1985) Anatomical and functional consequences of grafting mesencephalic neurons into a peripheral nerve bridge connected to the denervated striatum. Exp Brain Res 60:584-589.

Gundersen HJG, Jensen EB (1987) The efficiency of systematic sampling in stereology and its prediction. J Microsc 147:229-263.

Hammarberg H, Piehl F, Cullheim S, Fjell J, Hokfelt T, Fried K (1996) GDNF mRNA in Schwann cells and DRG satellite cells after chronic sciatic nerve injury. NeuroReport 7:857-860.

Henderson CE, Phillips HS, Pollock RA, Davies AM, Lemeulle C, Armanini M, Simpson LC, Moffet B, Vandlen RA, Koliatsos VE, Rosenthal A (1994) GDNF: a potent survival factor for motoneurons present in peripheral nerve and muscle. Science 266:1062-1064.

Heumann R, Lindholm D, Bandtlow C, Meyer M, Radeke MJ, Misko TP, Shooter E, Thoenen H (1987) Differential regulation of mRNA encoding nerve growth factor and its receptor in rat sciatic nerve during development, degeneration, and regeneration: role of macrophages. Proc Natl Acad Sci USA 84:8735-8739.

Ide C, Tohyama K, Yokota R, Nitatori T, Onodepa H (1983) Schwann cell basal lamina and nerve regeneration. Brain Res 288:61-65.

Johansson M, Friedemann M, Hoffer B, Stromberg I (1995) Effects of glial-cell line-derived neurotrophic factor on developing and mature ventral mesencephalic grafts in oculo. Exp Neurol 134:25-34.

Kordower JH, Freeman TB, Snow BJ, Vingerhoets FJG, Mufson EJ, Sanberg PR, Rosenstein JM, Collier TJ, Olanow CW (1995) Longterm fetal nigral graft survival and putamenal innervation correlates with functional recovery in a patient with Parkinson's disease-a clinical pathological analysis. Exp Neurol 135:166.

Kromer LF, Cornbrooks CJ (1985) Transplants of Schwann cell cultures promote axonal regeneration in the adult mammalian brain. Proc Natl Acad Sci USA 82:6330-6334.

Lapchak PA, Jiao S, Collins F, Miller PJ (1997) Glial cell line-derived neurotrophic factor: distribution and pharmacology in the rat following a bolus intraventricular injection. Brain Res 747:92-102.

Lee DA, Zurawel RH, Windebank AJ (1995) Ciliary neurotrophic factor expression in Schwann cells is induced by axonal contact. J Neurochem 65:564-568.

Leroy A, Michelet D, Mahieux F, Geny C, Defer G, Monfort JC, Degos JD, Nguyen JP, Peschanski M, Cesaro P (1996) Neuropsychological assessment of 5 parkinsonian patients before and after neuronal graft. Rev Neurol (Paris) 152:158-164.

Lin LFH, Doherty DH, Lile JD, Bektesh S, Collins F (1993) GDNF-a glial-cell line derived neurotrophic factor for midbrain dopaminergic neurons. Science 260:1130-1132.

Lindholm D, Heumann R, Meyer M, Thoenen H (1987) Interleukin-1 regulates synthesis of nerve growth factor in non-neuronal cells of rat sciatic nerve. Nature 330:658-659.

Lindvall O (1997) Neural transplantation: a hope for patients with Parkinson's disease. NeuroReport 8:3-8.

Lindvall O, Brundin P, Widner H, Rehncrona S, Gustavii B, Frackowiak R, Leenders KL, Sawle G, Rothwell JC, Marsden CD, Björklund A (1990) Grafts of fetal dopamine neurons survive and improve motor function in Parkinson's disease. Science 247:574-577.

Littlewood TD, Hancock DC, Danielian PS, Parker MG, Evan GI (1995) A modified oestrogen receptor ligand-binding domain as an improved switch for the regulation of heterologous proteins. Nucleic Acids Res 23:1686-1690.

Martini R (1994) Expression and functional roles of neural cell surface 
molecules and extracellular matrix components during development and regeneration of peripheral nerves. J Neurocytol 23:1-28.

Meyer M, Matsuoka I, Wetmore C, Olson L, Thoenen H (1992) Enhanced synthesis of brain-derived neurotrophic factor in the lesioned peripheral nerve: different mechanisms are responsible for the regulation of BDNF and NGF mRNA. J Cell Biol 119:45-54.

Nikkhah G, Cunningham MG, McKay R, Björklund A (1995) Dopaminergic microtransplants into the substantia nigra of neonatal rats with bilateral 6-OHDA lesions. II. Transplant-induced behavioral recovery. J Neurosci 15:3562-3570.

Nosrat CA, Tomac A, Lindqvist E, Lindskog S, Humpel C, Stromberg I, Ebendal T, Hoffer BJ, Olson L (1996) Cellular expression of GDNF mRNA suggests multiple functions inside and outside the nervous system. Cell Tissue Res 286:191-207.

Nosrat CA, Tomac A, Hoffer BJ, Olson L (1997) Cellular and developmental patterns of expression of Ret and glial cell line-derived neurotrophic factor receptor $\alpha$ mRNAs. Exp Brain Res 115:410-422.

Olanow CW, Kordower JH, Freeman TB (1996) Fetal nigral transplantation as a therapy for Parkinson's disease. Trends Neurosci 19:102-109.

Pasleau F, Tocci MJ, Leung F, Kopchick JJ (1985) Growth hormone gene expression in eukaryotic cells directed by the rous sarcoma virus long-terminal repeat or cytomegalo virus immediate-early promoter. Gene 38:227-232.

Perlow MJ, Freed WJ, Hoffer BJ, Sieger A, Olson L, Wyatt RJ (1979) Brain grafts reduce motor abnormalities produced by destruction of nigrostriatal dopamine system. Science 204:643-647.

Politis MJ, Ederle K, Spencer PS (1982) Tropism in nerve regeneration in vivo. Attraction of regenerating axons by diffusible factors derived from cells in distal nerve stumps of transected peripheral nerves. Brain Res 253:1-12.

Pong K, Xu RY, Beck KD, Zhang TJ, Louis JC (1997) Inhibition of glial cell line-derived neurotrophic factor induced intracellular activity by K-252b on dopaminergic neurons. J Neurochem 69:986-994.

Rosenblad C, Martinez-Serrano A, Björklund A (1996) Glial cell linederived neurotrophic factor increases survival, growth and function of intrastriatal fetal nigral dopaminergic grafts. Neuroscience 75:979-985.

Rufer M, Flanders K, Unsicker K (1994) Presence and regulation of transforming growth factor $\beta$ messenger RNA and protein in the normal and lesioned rat sciatic nerve. J Neurosci Res 39:412-423.

Schmued LC, Fallon JH (1986) Fluoro-gold: a new fluorescent retro- grade axonal tracer with numerous unique properties. Brain Res 377:147-154.

Sinclair SR, Svendsen CN, Torres EM, Martin D, Fawcett JW, Dunnett SB (1996) GDNF enhances dopaminergic cell survival and fibre outgrowth in embryonic nigral grafts. NeuroReport 7:2547-2552.

Torres EM, Rogers DC, Annett LE, Sirinathsinghji DJS, Dunnett SB (1993) A novel population of tyrosine-hydroxylase immunoreactive neurons in the basal forebrain of the common marmoset (Callithrix jacchus). Neurosci Lett 150:29-32.

Tseng JL, Baetge EE, Zurn AD, Aebischer P (1997) GDNF reduces drug-induced rotational behavior after medial forebrain bundle transection by a mechanism not involving striatal dopamine. J Neurosci 17:325-333.

Ungerstedt U (1968) 6-Hydroxydopamine-induced degeneration of central monoamine neurons. Eur J Pharmacol 5:107-110.

Vaudano E, Campbell G, Anderson PN, Davies AP, Woolhead C, Schreyer DJ, Lieberman AR (1995) The effects of a lesion or peripheral nerve graft on GAP-43 upregulation in the adult rat brain: an in situ hybridization and immunocytochemical study. J Neurosci 15:3594-3611.

Vaudano E, Campbell G, Hunt SP (1996) Change in the molecular phenotype of Schwann cells upon transplantation into the central nervous system: downregulation of c-jun. Neuroscience 74:553-565.

Wang Y, Tien LT, Lapchak PA, Hoffer BJ (1996) GDNF triggers fiber outgrowth of fetal ventral mesencephalic grafts from nigra to striatum in 6-OHDA-lesioned rats. Cell Tissue Res 286:225-233.

Wenning GK, Odin P, Morrish P, Rehncrona S, Widner H, Brundin P, Rothwell JC, Brown R, Gustavii B, Hagell P, Jahanshahi M, Sawle G, Bjorklund A, Brooks DJ, Marsden CD, Quinn NP, Lindvall O (1997) Short- and long-term survival and function of unilateral intrastriatal dopaminergic grafts in Parkinson's disease. Ann Neurol 42:95-107.

Winkler C, Sauer H, Lee CS, Björklund A (1996) Short-term GDNF treatment provides long-term rescue of lesioned nigral dopaminergic neurons in a rat model of Parkinson's disease. J Neurosci 16:7206-7215.

Xu XM, Guénard V, Kleitman N, Bunge MB (1995) Axonal regeneration into Schwann cell-seeded guidance channels grafted into transected adult rat spinal cord. J Comp Neurol 351:145-160.

Zhou FC, Chiang YH, Wang Y (1996) Constructing a new nigrostriatal pathway in the parkinsonian model with bridged neural transplantation in substantia nigra. J Neurosci 16:6965-6974. 